\title{
Zooplankton Community Responses in a Perturbed Tropical Stream in the Niger Delta, Nigeria
}

\author{
Francis O. Arimoro ${ }^{1,2 *}$ and Andrew O. Oganah ${ }^{2}$ \\ ${ }^{I}$ Institute for Water Research, Rhodes University, P.O Box 94, Grahamstown 6140, South Africa \\ ${ }^{2}$ Department of Animal and Environmental Biology, Delta State University, P.M.B 1 Abraka, Nigeria
}

\begin{abstract}
The effect of abattoir wastes and other anthropogenic activities on the distribution and abundance of zooplankton and environmental variables were investigated in Orogodo River, southern Nigeria. Samples of zooplankton were collected for a period of six months from three stations, representing upstream of the river course, effluent discharge point and downstream of the river course. A combined total of 79 species of zooplankton were encountered in the study. Station 1 recorded the highest number (78 species), station 2 with 22 taxa and station 3 with 72 representative taxa, showing recovery in terms of diversity and abundance of zooplankton. Rotifers of the order Bdelloidea dominated all the stations and were relatively high in station 2 indicating their tolerance to a wide range of impact. Generally, the cladocerans were abundant at all stations. However, Moina micrura, and Thermocylops neglectus were the only members of this group recorded in station 2. The low fauna diversity experienced in station 2 throughout the period of sampling showed strong evidence of impact arising from the abattoir waste discharge and heavy human activities at that station. Local environmental conditions (i.e. Temperature, flow velocity, depth, dissolved oxygen, alkalinity and conductivity) accounted for $69 \%$ of variation in zooplankton assemblages using canonical correspondence analysis (CCA). Seasonal trends in zooplankton community composition were also related to changes in environmental characteristics of the river. Our results indicate that the changing water quality status of the Orogodo River affected the zooplankton diversity and abundance and such measure could be used as a biomonitoring tool to determine the ecological health of the river.
\end{abstract}

Keywords: Zooplankton, Orogodo river, organic pollution, environmental variables, Nigeria.

\section{INTRODUCTION}

River pollution is becoming a critical issue of water management in Nigeria, especially in urban and semi urban cities. Many rivers in urban and semi urban areas of Nigeria have been used for disposals of both solid wastes and waste waters, usually untreated, and are thus adversely polluted. This high pollution status threatens and, in many cases, has already altered the ecological balance of most rivers in Nigeria [1-3]. Zooplankters offer several advantages as indicators of environmental quality in both lakes and rivers: as a group, they have worldwide distribution and the species composition and community structure are sensitive to changes in environmental conditions, nutrient enrichment [4-6] and different levels of pollution [7-9]. Zooplankton play an important ecological role in lakes and rivers, feeding on non-living organic matter, phytoplankton and bacteria, and in turn being eaten by secondary consumers such as fish [10]. The physico- chemical parameters of an aquatic ecosystem are very important in assessing the composition of any aquatic biota and also their sensitivity to pollution $[5,10,11]$. Therefore, a major interest in zooplankton investigation is to understand environmental factors that influence their diversity [12]. Certain knowledge of the responses of zooplankton to changes

*Address correspondence to this author at the Institute for Water Research, Rhodes University, P.O Box 94, Grahamstown 6140, South Africa; Tel +27710535860; E-mails: fransarimoro@yahoo.com; f.arimoro@ru.ac.za in water quality could therefore constitute an important tool to be used by water managers in Nigeria to continually and rapidly assess the health of the water bodies. Some researchers in the tropics $[13,14]$ have reported higher densities of zooplankton in the rainy season, with copepod forming the dominant group, followed by cladocerans, rotifers and ostracods [15] had earlier suggested that since most of these factors are influenced by rainfall, rainfall regime is therefore considered a dominant factor affecting zooplankton dynamics in tropical waters. Orogodo River is one of the numerous freshwater bodies that abound in the Niger Delta area of southern Nigeria. It is a typical municipal stream flowing through Agbor town with a population of over 100,000 people. The stream at the middle reaches is subjected to organic pollution load arising from the effluent discharged from the abattoir comprising of stomach and intestinal contents of slaughtered animals, ashes of burnt animals and associated bloodstains. An average of 400 animals are slaughtered daily which makes up an enormous volume of wastes discharge regularly in the stream without treatment. Furthermore, the river is influenced by frequent disturbance of humans and domestic animals and if not properly managed can pose severe health risk to the population. Downstream from the $\mathrm{Ag}$ bor abattoir, water is used for vegetable farming in the catchment as oppose to its use as portable water upstream. The continuous discharge of these organic wastes into the water body and the dearth of information on the responses of aquatic biota including zooplankton to these wastes necessi- 
tate this research. In the Niger delta area of Nigeria, zooplankton has been mostly monitored in lake studies [16, 17]. There have been no comprehensive zooplankton studies in the Delta State River system. This paper aims to partly fill an existing gap in zooplankton biodiversity knowledge of the Niger Delta area in Nigeria and their use to evaluate river health. Also the zooplankton community characteristics will be utilized in assessing the recovery of the river following stress caused by anthropogenic activities.

\section{MATERIALS AND METHODS}

\section{Description of Study Area}

Orogodo River lies between latitude $5.10^{1}-6.20^{1} \mathrm{~N}$ and longitude $6.10^{1}-6.21{ }^{1} \mathrm{E}$ (Fig. 1). The river is fed principally by ground seepage from an aquifer in the thick rainforest of Mbiri and secondarily by precipitation, municipal effluence and surface run off from the riparian communities. The river flows through the major town of Agbor in southern Nigeria. The river substratum consists mainly of fine sand mixed with mud and occasionally with coarse sand and pebbles. Decaying macrophytes and debris also form part of the substratum. The climate of Agbor town and its environs is characterized by a rhythm of rainfall occurring in conjunction with movements of the southwest Monsoon winds across the Atlantic Ocean and the timing of these movements varies from year to year. The dry season is from November to March and the wet season is from April to October. The sampling sites and their location are given below:

\section{Station 1}

The station is located approximately $2 \mathrm{~km}$ from the river's source (Fig. 1). The water here flows beneath a dense tree canopy in a shallow channel $(0.5 \mathrm{~m}$ deep, $5.4 \mathrm{~m}$ wide at the station) joining shallow pools at various points. Aquatic vegetation is thick consisting of both submerged macrophytes (Ceratophyllum submersum L, Azolla Africana (Desv.), Utricularia sp) and emergent macrophytes (Pycreus lanceolatus Pol, Cytosperma senegalense (EngL.), Scirpus jacobi (Fisher) and Vossia cuspidata (Griff)). The streambed is loam and silt with fallen leaves. No point source of pollution is found here [18]. The marginal vegetation is composed of terrestrial plants including oil palm (Elaeis guineensis) and Indian bamboo (Bambusa sp). The water velocity at this station is considerably low with a mean of $0.20 \mathrm{~m} / \mathrm{s}$. Human activity is considerably less than at downstream stations, but fishing with hook and line is commonly practiced at this station.

\section{Station 2}

The station is located at the point of discharge of effluents from the Agbor Abattoir. The abattoir effluent is mainly organic, made up of faeces, blood and ashes produced during the slaughter, roasting and burning of animals (donkeys and cows). This station is exposed to direct heat of the sun and has heavy algal growth in some areas but, with very few macrophytes (Nymphae lotus, Azolla sp., Utricularia sp and Salvinia sp) and duckweeds (Lemna) closed to the banks. The streambed is covered by coarse sand. The current veloc-

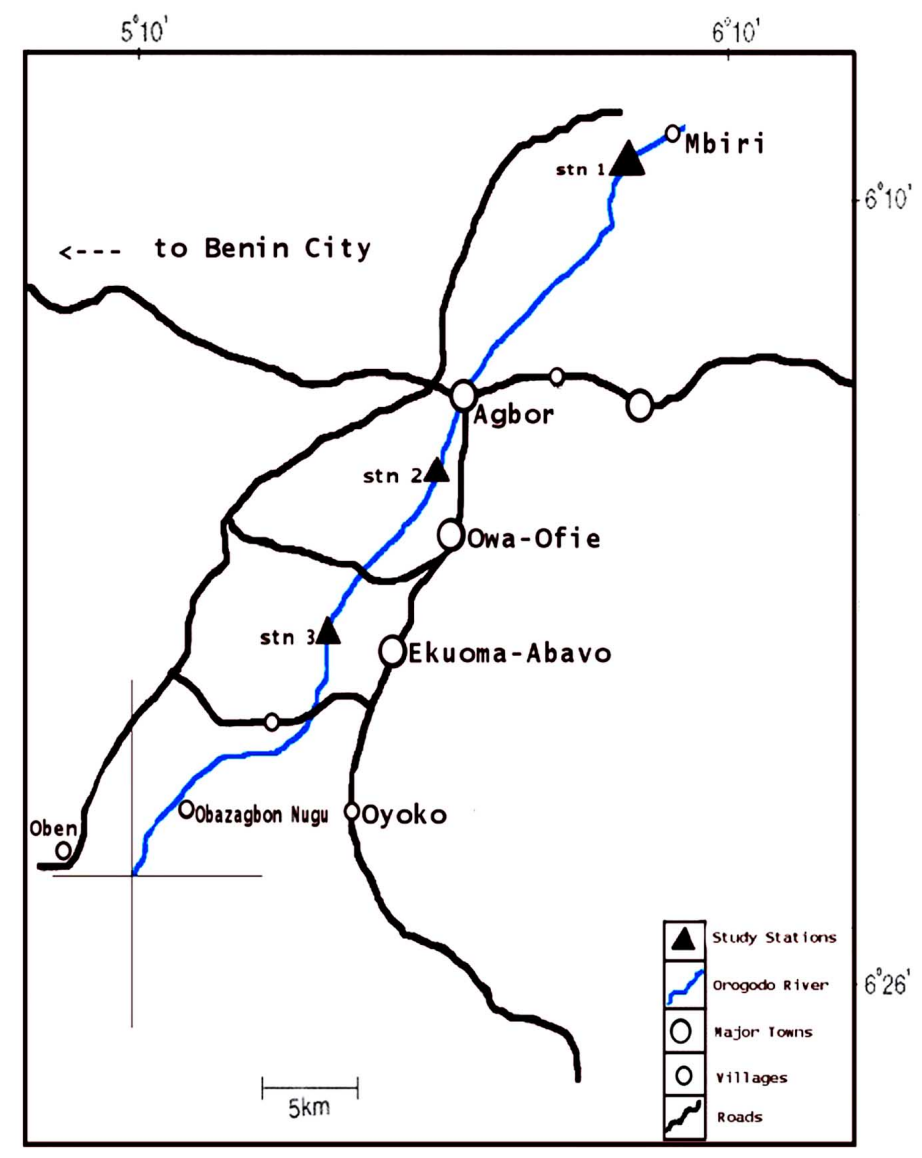

Fig. (1). Map of Orogodo River showing the location of the sampling stations. 
Table 1. Environmental Factors Measured at the Sampling Stations of Orogodo River, (Jan-Jun 2008) Showing Physico-Chemical Parameters $(n=6)$.

\begin{tabular}{|c|c|c|c|}
\hline Physicochemical Parameters & Station 1 & Station 2 & Station 3 \\
\hline Air temperature $\left({ }^{\circ} \mathrm{C}\right)$ & $\begin{array}{l}22.80 \pm 0.07^{\mathrm{a}} \\
(22.00-23.48)\end{array}$ & $\begin{array}{c}24.3 \pm 0.21^{\mathrm{a}} \\
(24.00-25.35)\end{array}$ & $\begin{array}{l}23.17 \pm 0.31^{\mathrm{a}} \\
(22.00-24.48)\end{array}$ \\
\hline Depth (metres) * & $\begin{array}{l}1.46 \pm 0.02^{\mathrm{a}} \\
(1.36-1.60)\end{array}$ & $\begin{array}{c}0.70 \pm 0.04^{\mathrm{b}} \\
(0.58-0.80)\end{array}$ & $\begin{array}{l}1.33 \pm 0.03^{\mathrm{a}} \\
(1.25-1.40)\end{array}$ \\
\hline Flow velocity $(\mathrm{m} / \mathrm{s})$ * & $\begin{array}{l}0.04 \pm 0.00^{\mathrm{a}} \\
(0.04-0.05)\end{array}$ & $\begin{array}{c}0.32 \pm 0.03^{\mathrm{b}} \\
(0.21-0.43)\end{array}$ & $\begin{array}{c}0.21 \pm 0.02^{\mathrm{c}} \\
(0.11-0.25)\end{array}$ \\
\hline Alkalinity $(\mathrm{mg} / \mathrm{l})$ * & $\begin{array}{l}14.93 \pm 0.55^{\mathrm{a}} \\
(13.32-17.85)\end{array}$ & $\begin{array}{l}5.17 \pm 0.67^{b} \\
(4.11-7.54)\end{array}$ & $\begin{array}{l}8.54 \pm 1.87^{\mathrm{c}} \\
(6.08-17.86)\end{array}$ \\
\hline $\mathrm{pH}$ & $\begin{array}{c}5.8 \\
(5.3-6.1)\end{array}$ & $\begin{array}{c}5.9 \\
(5.8-6.7)\end{array}$ & $\begin{array}{c}5.9 \\
(5.4-6.4)\end{array}$ \\
\hline Nitrates $(\mathrm{mg} / \mathrm{l})$ * & $\begin{array}{l}0.43 \pm 0.19^{a} \\
(0.22-0.88)\end{array}$ & $\begin{array}{c}1.72 \pm 0.39^{\mathrm{b}} \\
(0.89-2.87)\end{array}$ & $\begin{array}{l}1.56 \pm 0.18^{\mathrm{b}} \\
(1.28-2.34)\end{array}$ \\
\hline Phosphates $(\mathrm{mg} / \mathrm{l})$ * & $\begin{array}{c}0.05 \pm 0.01^{\mathrm{a}} \\
(0.01-0.08)\end{array}$ & $\begin{array}{c}0.08 \pm 0.01^{\mathrm{b}} \\
(0.06-0.10)\end{array}$ & $\begin{array}{c}0.04 \pm 0.02^{\mathrm{a}} \\
(0.01-0.09)\end{array}$ \\
\hline
\end{tabular}

Note. Values are mean \pm SE, range in parenthesis, * indicates significantly calculated F-value detected by ANOVA. Different superscript letters (a, b and c) in a row show significant differences $(\mathrm{P}<0.05)$ indicated by Tukey Honest (HSD) significant difference tests.

ity is relatively fast (mean value $=0.58 \mathrm{~m} \mathrm{~s}-1$ ). Average depth is about $0.5 \mathrm{~m}$ and width $5.8 \mathrm{~m}$. Domestic wastes from the town are emptied few kilometers from this station during heavy down pour. In addition, washing of cars and clothes with detergents occurs regularly here. This station has the greatest anthropogenic impact [18].

\section{Station 3}

The station is located $5 \mathrm{~km}$ downstream from the Agbor Abattoir close to Abavo by Owa-Ofie village. The riverbed widens considerably $(10.4 \mathrm{~m})$ at this point. Farming and sand dredging are the predominant land uses, so the riparian vegetation of the area could be described as farm bush. Most of this section of the river is flanked by Indian bamboo (Bambusia sp) and palm (Elaeis guineenis), Pandanus sp., and Mitragyna ciliata. The current velocity is relatively fast (mean $=0.47 \mathrm{~m} \mathrm{~s}-1)$. The substratum is predominantly clay and silt. Human activities include bathing, fishing, contamination with uneaten food by worshippers, etc. The water depth is approximately $0.75 \mathrm{~m}$.

\section{Samples Collection}

Samples of water and zooplankton were collected monthly from each site from January to June 2008 covering three months each in the dry season (January - March) and wet season (April - June) respectively on same sampling days. Surface water temperatures were recorded with mercury in glass thermometer. Conductivity, $\mathrm{pH}$, total alkalinity, dissolved oxygen and biochemical oxygen demand (BOD) were determined according to [19] methods. The surface water velocity measured in mid channel by timing a float (average of three trials) as it moved over a distance of $10 \mathrm{~m}$ [20]. Depth was measured in the sample area using a calibrated stick. Nitrate-nitrogen (NO3-N) and phosphate phosphorus (PO4-P) were measured spectrophotometrically after reduction with appropriate solutions [19]. Substratum composition in each $25 \mathrm{~m}$ sampling reach was estimated visually as percentage of silt, loam and sand [21]. Zooplankton was sampled quantitively in the mid channel at all sites. Vertical hauls were taken using plankton townet of mesh size $80 \mathrm{~m}$ (172 meshes/inch) as described by [22]. The samples were preserved in $4 \%$ buffered formalin solution and transported back to the laboratory. Taxonomic identification was conducted under a microscope at a magnification of $40 \mathrm{x}$ and $100 \mathrm{x}$. Zooplankton organisms were identified to the species level according to [23-26] and abundance estimated.

\section{Data Collection and Analysis}

A faunal list was compiled by recording all zooplankton taxa found in the sampling stations (Table 2). The range, mean and standard error for each parameter and station were 
Table 2. Composition, Distribution and Mean Abundance of Zooplankton in Orogodo River from January to June 2008

\begin{tabular}{|c|c|c|c|c|c|c|c|}
\hline \multirow[t]{2}{*}{ TAXONOMIC GROUP } & \multirow[t]{2}{*}{ Code } & \multicolumn{3}{|c|}{ STATIONS } & \multirow[t]{2}{*}{$\begin{array}{c}\text { Percentage } \\
\text { Composition }\end{array}$} & \multicolumn{2}{|c|}{$\begin{array}{c}\text { Seasonal } \\
\text { Occurrence }\end{array}$} \\
\hline & & 1 & 2 & 3 & & DS & RS \\
\hline \multicolumn{8}{|l|}{ Family Asplanchnidae } \\
\hline Asplanchna brightwellii Gosse, 1850 & & $\mathrm{x}$ & - & $\mathrm{x}$ & 0.1 & & + \\
\hline Platyias quadricornis Ehrenberg, 1832 & & $\mathrm{x}$ & - & - & 0.1 & & + \\
\hline Keratella sp. Bory de St. Vincent, 1822 & Ker & $\mathrm{x}$ & - & $\mathrm{x}$ & 1.3 & + & + \\
\hline Branchionus calyciflorus Pallas, 1776 & Bra & $\mathrm{x}$ & - & $\mathrm{x}$ & 0.6 & + & + \\
\hline Branchionus variabilis Hempel, 1896 & $\mathrm{Bra}$ & $\mathrm{x}$ & - & $\mathrm{x}$ & 0.8 & + & + \\
\hline Colurella uncinata Müller, 1773 & & $\mathrm{x}$ & - & $\mathrm{x}$ & 0.2 & & + \\
\hline Lepadella (Xenolepadella) monodactyla Berzins, 1960 & & $\mathrm{x}$ & - & $\mathrm{x}$ & 0.5 & & + \\
\hline \multicolumn{8}{|l|}{ Family Dicranophoridae } \\
\hline Aspelta tilba Koste \& Shiel, 1987 & Asp & $\mathrm{x}$ & - & $\mathrm{x}$ & 1.1 & + & + \\
\hline \multicolumn{8}{|l|}{ Family Euchlanidae } \\
\hline Euchlanis dilatata Ehrenberg, 1832 & & $\mathrm{x}$ & - & - & 0.2 & & + \\
\hline \multicolumn{8}{|l|}{ Family Gastropodidae } \\
\hline Ascomorpha ecaudis Perty, 1850 & Asc & $\mathrm{x}$ & - & $\mathrm{x}$ & 0.8 & + & + \\
\hline \multicolumn{8}{|l|}{ Family Lecanidae } \\
\hline Lecane acronycha Harrings and Myers & Lec & $\mathrm{x}$ & $\mathrm{x}$ & $\mathrm{x}$ & 1.9 & + & + \\
\hline Lecane luna Müller, 1776 & Lec & $\mathrm{x}$ & - & $\mathrm{x}$ & 0.2 & & + \\
\hline Lecane papuana Murray, 1913 & Lec & $\mathrm{x}$ & - & $\mathrm{x}$ & 0.5 & + & \\
\hline Lecane monostyla Daday, 1897 & Lec & $\mathrm{x}$ & - & $\mathrm{x}$ & 0.6 & + & + \\
\hline Lecane quadrindentata, Ehrenberg, 1832 & Lec & $\mathrm{x}$ & $\mathrm{x}$ & $\mathrm{x}$ & 0.8 & & + \\
\hline Lecane decipiens Murray 1913 & Lec & $\mathrm{x}$ & - & $\mathrm{x}$ & 0.9 & + & + \\
\hline Lecane grandis Murray, 1913 & Lec & $\mathrm{x}$ & $\mathrm{x}$ & $\mathrm{x}$ & 1.1 & + & + \\
\hline Monostyla sinuate Hauer, 1938 & Mon & $\mathrm{x}$ & - & $\mathrm{x}$ & 1.0 & & + \\
\hline Monostyla bulla bulla Goose, 1851 & Mon & $\mathrm{x}$ & - & $\mathrm{x}$ & 0.5 & + & + \\
\hline Monostyla cornuta Mueller, 1786 & Mon & $\mathrm{x}$ & - & $\mathrm{x}$ & 2.5 & + & + \\
\hline Monostyla lunaris Ehrenberg, 1832 & Mon & $\mathrm{x}$ & - & $\mathrm{x}$ & 3.0 & + & + \\
\hline \multicolumn{8}{|l|}{ Family Proalidae } \\
\hline Proales sp Goose, 1886 & Pro & $\mathrm{x}$ & $\mathrm{x}$ & $\mathrm{x}$ & 0.9 & & + \\
\hline \multicolumn{8}{|l|}{ Family Trichocercidae } \\
\hline Trichocerca tropis Hauer, 1937 & Tri & $\mathrm{x}$ & - & $\mathrm{x}$ & 0.1 & & + \\
\hline
\end{tabular}


Table 2. contd...

\begin{tabular}{|c|c|c|c|c|c|c|c|}
\hline \multirow[t]{2}{*}{ TAXONOMIC GROUP } & \multirow[b]{2}{*}{ code } & \multicolumn{3}{|c|}{ STATIONS } & \multirow[t]{2}{*}{$\begin{array}{c}\text { Percentage } \\
\text { Composition }\end{array}$} & \multicolumn{2}{|c|}{$\begin{array}{c}\text { Seasonal } \\
\text { Occurrence }\end{array}$} \\
\hline & & 1 & 2 & 3 & & DS & RS \\
\hline Trichocerca elongata Murray, 1913 & Tri & $\mathrm{x}$ & - & $\mathrm{x}$ & 0.4 & + & \\
\hline Trichocerca longiseta Schrank, 1802 & Tri & $\mathrm{x}$ & - & $\mathrm{x}$ & 0.5 & + & + \\
\hline Trichocerca iernis Gosse, 1887 & Tri & $\mathrm{x}$ & $\mathrm{x}$ & $\mathrm{x}$ & 0.3 & & + \\
\hline Trichocerca obtusidens Olofssons, 1918 & Tri & $\mathrm{x}$ & $\mathrm{x}$ & $\mathrm{x}$ & 0.5 & & + \\
\hline \multicolumn{8}{|l|}{ Family Trichotridae } \\
\hline Macrochaetus collinsi Gosse, 1867 & Mac & $\mathrm{x}$ & $\mathrm{x}$ & $\mathrm{x}$ & 0.5 & + & + \\
\hline \multicolumn{8}{|l|}{ ORDER BDELLOIDAE } \\
\hline \multicolumn{8}{|l|}{ Family Adinetidae } \\
\hline Adineta gracilis Janson, 1893 & & $\mathrm{x}$ & - & - & 0.2 & & + \\
\hline \multicolumn{8}{|l|}{ Family Habrotrochidae } \\
\hline Otostephanus sp Milne, 1916 & Oto & $\mathrm{x}$ & $\mathrm{x}$ & $\mathrm{x}$ & 1.9 & + & + \\
\hline Habrotrocha sp Bryce, 1910 & $\mathrm{Hab}$ & $\mathrm{x}$ & $\mathrm{x}$ & $\mathrm{x}$ & 2.0 & + & + \\
\hline \multicolumn{8}{|l|}{ Family Philodinavidae } \\
\hline Philodinavus paradoxus Murray, 1905 & Phi & & $\mathrm{x}$ & $\mathrm{x}$ & 1.6 & + & + \\
\hline \multicolumn{8}{|l|}{ Family Philodinidae } \\
\hline Rotaria rotatoria Pallas, 1766 & Rot & $\mathrm{x}$ & $\mathrm{x}$ & $\mathrm{x}$ & 6.0 & + & + \\
\hline Rotaria tridens Montet, 1915 & Rot & $\mathrm{x}$ & $\mathrm{x}$ & $\mathrm{x}$ & 9.0 & + & + \\
\hline Rotaria tardigrada Ehrenberg, 1832 & Rot & $\mathrm{x}$ & $\mathrm{x}$ & $\mathrm{x}$ & 1.0 & + & + \\
\hline Rotaria macroceros Gosse, 1851 & Rot & $\mathrm{x}$ & $\mathrm{x}$ & $\mathrm{x}$ & 2.4 & + & + \\
\hline Rotaria macrura Schrank, 1802 & Rot & $\mathrm{x}$ & $\mathrm{x}$ & $\mathrm{x}$ & 1.7 & + & + \\
\hline Philodina roseola Ehrenberg, 1832 & & $\mathrm{x}$ & $\mathrm{x}$ & $\mathrm{x}$ & 1.3 & + & + \\
\hline Dissotrocha aculeata Ehrenberg, 1832 & & $\mathrm{x}$ & - & $\mathrm{x}$ & 0.2 & & + \\
\hline Macrotrachela sp Milne, 1886 & & $\mathrm{x}$ & $\mathrm{x}$ & $\mathrm{x}$ & 1.5 & + & + \\
\hline \multicolumn{8}{|l|}{ Family Notominatidae } \\
\hline Cephalodella sp Bory de St. Vincent, 1826 & & $\mathrm{x}$ & - & $\mathrm{x}$ & 0.4 & & + \\
\hline \multicolumn{8}{|l|}{ ORDER FLOSCULARIACEA } \\
\hline \multicolumn{8}{|l|}{ Family Testudinellidae } \\
\hline Testudinella patina Hermann, 1783 & Tes & $\mathrm{x}$ & - & $\mathrm{x}$ & 1.4 & + & + \\
\hline Heraelia brema Dona, 1994 & & $\mathrm{x}$ & - & $\mathrm{x}$ & 0.7 & + & + \\
\hline Testudinella sp Bory de St. Vincent, 1826 & & $\mathrm{x}$ & - & $\mathrm{x}$ & $<0.1$ & & + \\
\hline \multicolumn{8}{|l|}{ Family Trochosphaeridae } \\
\hline Trochosphaera aequatorialis Semper, 1872 & & $\mathrm{x}$ & $\mathrm{x}$ & $\mathrm{x}$ & 1.3 & + & + \\
\hline \multicolumn{8}{|l|}{ SUBCLASS COPEPODA } \\
\hline \multicolumn{8}{|l|}{ ORDER CALANOIDA } \\
\hline \multicolumn{8}{|l|}{ Family Diaptomidae } \\
\hline Thermodiaptomus galebi Kiefer, 1927 & Dia & $\mathrm{x}$ & - & $\mathrm{x}$ & 0.2 & & + \\
\hline Tropodiaptomus incognitus Dussart, 1966 & Dia & $\mathrm{x}$ & - & $\mathrm{x}$ & 0.4 & & + \\
\hline Tropodiaptomus processifer Kiefer, 1927 & Dia & $\mathrm{x}$ & - & $\mathrm{x}$ & 2.1 & & + \\
\hline Thermodiaptomus yabensis Wright \& Tressler, 1928 & Dia & $\mathrm{X}$ & - & $\mathrm{x}$ & 0.6 & + & + \\
\hline \multicolumn{8}{|l|}{ Family Cyclopidae } \\
\hline Microcyclops rubellus Lilljeborg, 1901 & Mic & $\mathrm{x}$ & - & $\mathrm{x}$ & 2.8 & + & + \\
\hline Microcyclops varicans Sars, 1863 & Mic & $\mathrm{X}$ & - & $\mathrm{x}$ & 2.0 & + & + \\
\hline
\end{tabular}


Table 2. contd...

\begin{tabular}{|c|c|c|c|c|c|c|c|}
\hline \multirow[t]{2}{*}{ TAXONOMIC GROUP } & \multirow[b]{2}{*}{ Code } & \multicolumn{3}{|c|}{ STATIONS } & \multirow[t]{2}{*}{$\begin{array}{l}\text { Percentage Com- } \\
\text { position }\end{array}$} & \multicolumn{2}{|c|}{$\begin{array}{l}\text { Seasonal Occur } \\
\text { rence }\end{array}$} \\
\hline & & 1 & 2 & 3 & & DS & $\mathrm{RS}$ \\
\hline Halicyclops korodiensis Onabamiro, 1952 & $\mathrm{Hal}$ & $\mathrm{x}$ & - & $\mathrm{x}$ & 0.7 & & + \\
\hline Thermocyclops neglectus Sars, 1901 & The & $\mathrm{x}$ & $\mathrm{x}$ & $\mathrm{x}$ & 2.1 & + & + \\
\hline \multicolumn{8}{|l|}{ Family Canthocamptidae } \\
\hline Bryocamptus birsteini Borutskii, 1940 & Bry & $\mathrm{x}$ & - & $\mathrm{x}$ & 5.3 & + & + \\
\hline \multicolumn{8}{|l|}{ ORDER CLADOCERA } \\
\hline \multicolumn{8}{|l|}{ Family Moinidae } \\
\hline Moina micrura Kurz, 1874 & Moi & $\mathrm{x}$ & $\mathrm{x}$ & $\mathrm{x}$ & 3.3 & + & + \\
\hline \multicolumn{8}{|l|}{ Family Chydoridae } \\
\hline Eurylona orientalis Daday, 1898 & & $\mathrm{x}$ & - & $\mathrm{x}$ & 0.3 & & + \\
\hline Eurylona sp Sars, 1901 & & $\mathrm{x}$ & - & & 0.1 & + & + \\
\hline Chydorus reticulatus Daday, 1898 & Chy & $\mathrm{x}$ & - & $\mathrm{x}$ & 5.8 & + & + \\
\hline Chydorus ventricosus Daday, 1898 & Chy & $\mathrm{x}$ & - & $\mathrm{x}$ & 4.6 & + & + \\
\hline Alona eximia Kiser, 1948 & Alo & $\mathrm{x}$ & - & $\mathrm{x}$ & 0.5 & + & + \\
\hline Alona davidi Richard, 1895 & Alo & $\mathrm{x}$ & - & $\mathrm{x}$ & 2.1 & & + \\
\hline Alona rectangular Sars, 1861 & Alo & $\mathrm{x}$ & - & - & 0.1 & & + \\
\hline Oxyurella sp Dybowski \& Grochowski, 1894 & & $\mathrm{x}$ & - & $\mathrm{x}$ & 0.3 & + & \\
\hline \multicolumn{8}{|l|}{ Family Bosminidae } \\
\hline Bosmina longirostris Müller, 1785 & Bos & $\mathrm{x}$ & - & $\mathrm{x}$ & 0.3 & & + \\
\hline Bosminopsis deitersi Richard, 1895 & Bos & $\mathrm{x}$ & - & $\mathrm{x}$ & 0.6 & & + \\
\hline \multicolumn{8}{|l|}{ Family Macrothricidae } \\
\hline Macrothrix goeldi Richard, 1897 & & $\mathrm{x}$ & - & $\mathrm{x}$ & 0.7 & & + \\
\hline Echinisca capensis Sars, 1916 & & $\mathrm{x}$ & - & - & 0.2 & & + \\
\hline Guernella raphaelis Richard, 1892 & & $\mathrm{x}$ & - & - & 0.4 & + & + \\
\hline Echinisca triseralis Brady, 1886 & & $\mathrm{x}$ & - & $\mathrm{x}$ & 0.6 & + & + \\
\hline \multicolumn{8}{|l|}{ Family Daphnidae } \\
\hline Diaphanosoma excisum Sars, 1885 & Dap & $\mathrm{x}$ & $\mathrm{x}$ & $\mathrm{x}$ & 0.4 & + & + \\
\hline Cerodaphnia cornuta Sars, 1888 & Dap & $\mathrm{x}$ & - & $\mathrm{x}$ & 1.6 & + & + \\
\hline \multicolumn{8}{|l|}{ Family Sisidae } \\
\hline Pseudosida sp Herrick & & $\mathrm{x}$ & - & $\mathrm{x}$ & 2.3 & + & + \\
\hline \multicolumn{8}{|l|}{ OSTRACODA } \\
\hline Eucypris sp Vavra,1891 & & $\mathrm{x}$ & - & $\mathrm{x}$ & 0.5 & & + \\
\hline Nebalia bipes Fabricius, 1780 & & $\mathrm{x}$ & - & $\mathrm{x}$ & 0.4 & + & + \\
\hline
\end{tabular}

Note x-present, - absent, D.S- dry season, R.S- Rainy season, codes abbreviated for CCA analysis.

calculated. Physical and chemical features of stations were compared using one way ANOVA on $\log (\mathrm{x}+1)$ transformed data except for $\mathrm{pH}$. Fixed effect ANOVAs were performed using dates as replicates. Significant ANOVAs $(\mathrm{P}<0.05)$ were followed by post hoc $\{$ Tukey Honest (HSD) \} tests to identify differences between station means. Canonical correspondence analysis (CCA) was used to evaluate relationships between zooplankton communities and environmental variables with Brodgar statistical package (version 2.0, Highland Statistics Ltd, 2000). Before using CCA, variables that covaried with other variables (Pearson correlation $\mathrm{r}>0.80, \mathrm{P}<$ $0.05)$ were removed. Rare species $(<2 \%$ at a sampling site) were not included in the CCA. Although all physicochemicalparameters were included in the early CCA ordinations, 

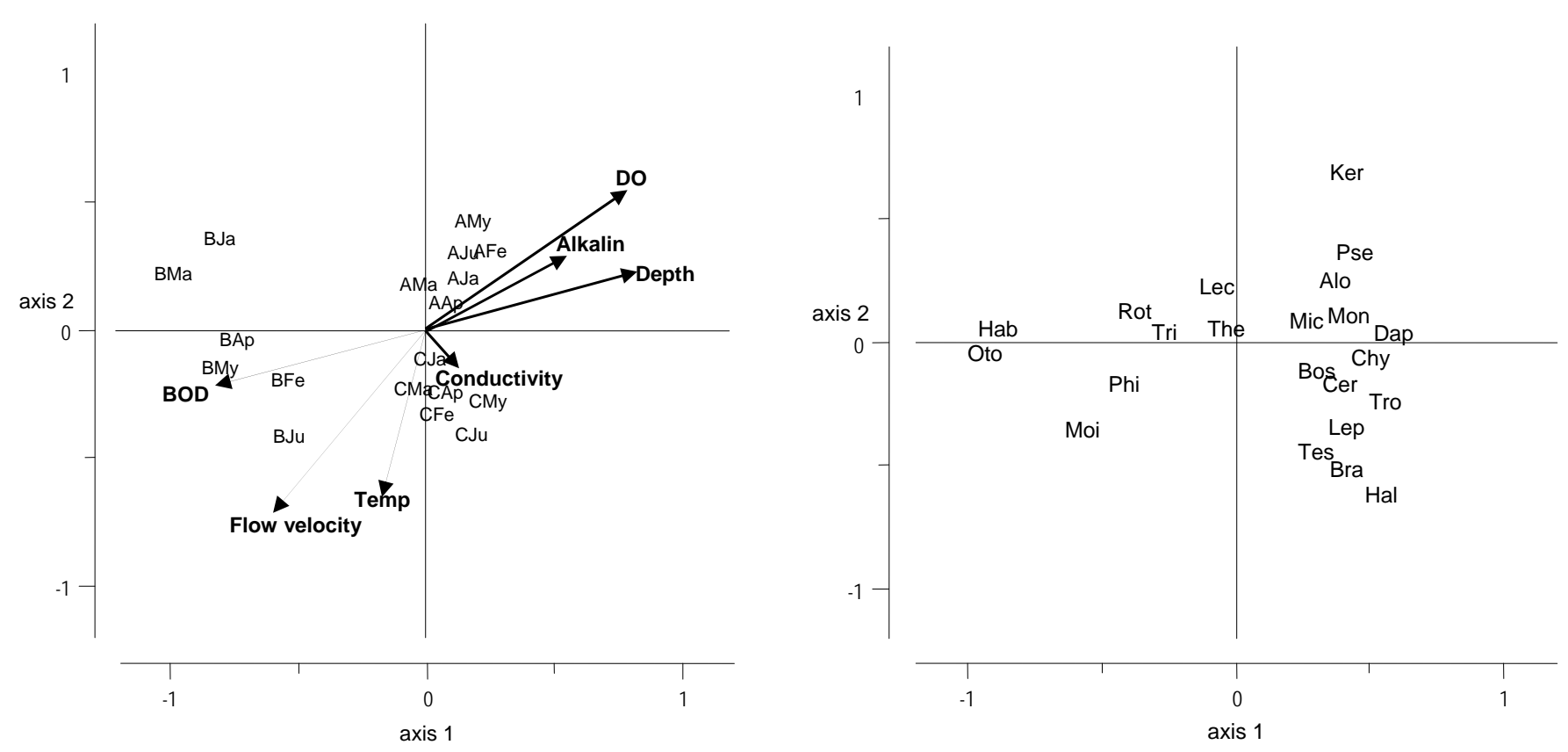

Fig. (2). Canonical correspondence analysis (CCA) ordination plots for $\mathbf{A}$, sites/stations and environmental variables and $\mathbf{B}$, species Code for genera in Table 2, (Monthly codes are Ja, January; Fe, February; Ma, March; Ap, April; My, May; Ju, June. Stations are 1, A; 2, B; and 3, C (Axes have a total eigenvalues of 0.19 and total inertia of 0.24 ).

those variables with high variance inflation factors $(\mathrm{VIF}>20$ indicating very strong multicollinearity) were eliminated from the analyses. In addition, variables were $\log$ transformed $\{\log (\mathrm{x}+1)\}$ before the CCA analysis to prevent extreme values (outlier) from unduly influencing the ordination. Species-environment correlation coefficients provided a measure of how well variation in community composition could be explained by individual environmental variables. A Monte Carlo permutation test with 199 permutations [27] was used to assess the significance of the canonical axes extracted. Taxa richness (Margalef \& Menhinick indices), diversity (Shannon, \& Simpson dominance indices), evenness indices and Hutcheson T-test for inter-station comparison were calculated using the computer BASIC programme SP DIVERS [28].

\section{RESULTS}

The range, mean and standard error of some selected water quality parameters used in delineating the effect of organic wastes (Abattoir effluent) and other anthropogenic activities on the distribution and abundance of zooplankton are summarized in Table 1. CCA ordination plots for sites and environmental variables and for species is shown in Fig. (2A and 2B) respectively. The CCA ordination showed a good relationship between zooplankton species distribution and measured environmental variables. The strongest explanatory factors were flow velocity, dissolved oxygen (DO) and biochemical oxygen demand (BOD). BOD was strongly negatively correlated with depth, dissolved oxygen and alkalinity. There was very weak correlation between DO and conductivity same as for BOD and conductivity. Moina, Philodinavus and Otostephanus species were common with the site with high BOD values. Similarly, Pseudosida, Keratella, Alona and Microcyclops species were common in the site with high DO values. Above $69 \%$ of variation in the species abundance data was accounted for by the environmental variables measured. Monte Carlo permutation test indicated that all axes were significant. The main environmental variables (axis 1) were determined by DO, depth, flow velocity, BOD and alkalinity (Fig. 2, Table 3). The second environmental variable was associated mainly with factors that changed seasonally, as shown by strong correlations with temperature and flow velocity. The composition and seasonal occurrence of zooplankton recorded in the various stations during the period of the study is shown in Table $\mathbf{2}$. Qualitatively, the fauna of each station was dominated by rotifers followed by cladocerans, copepods, and ostracods in that order. A combined total of 79 taxa were encountered. The rotifer fauna consisted of 49 species belonging to the orders, Plioma, Bdelloidea, and Flosculariacea. Station 1, had more representative taxa (78 species) in terms of diversity and abundance. The only species that was not recorded in this station was the bdelloid rotifer, Philodinavus paradoxus. Station 2 recorded very few representative taxa [22] in relatively low abundance. The zooplankton community was restricted to bdelloid rotifers, the cladoceran, Moina micrura and Daphnanosoma excisum. In contrast however, 
Table 3. Pearson Correlation Between Zooplankton Density and Environmental Variables and Weighted Intraset Correlation with the Axes of Canonical Correspondence Analysis (CCA) in the Study Area

\begin{tabular}{|c|c|c|c|}
\hline Environmental Variables & Total Zooplankton Density & Axis 1 & Axis 2 \\
\hline \hline Dissolved oxygen $(\mathrm{mg} / \mathrm{l})$ & $0.96^{* *}$ & $0.79^{* *}$ & -0.16 \\
\hline Water temperature $\left({ }^{0} \mathrm{C}\right)$ & 0.29 & $0.93^{* *}$ & $-0.66^{* *}$ \\
\hline Water depth $(\mathrm{m})$ & $0.95^{* *}$ & $-0.60^{*}$ & -0.22 \\
\hline Flow velocity $(\mathrm{m} / \mathrm{s})$ & $0.60^{*}$ & $-0.92^{* *}$ & -0.25 \\
\hline BOD $_{5}(\mathrm{mg} / \mathrm{l})$ & $0.74^{* *}$ & 0.14 & -0.18 \\
\hline Conductivity $(\mu \mathrm{S} / \mathrm{m})$ & $-0.72^{* *}$ & $0.64^{*}$ & $0.34^{*}$ \\
\hline Total alkalinity $(\mathrm{mg} / \mathrm{l})$ & $0.48^{*}$ & & \multicolumn{2}{|c|}{} \\
\hline
\end{tabular}

* Significantly different at $\mathrm{p}<0.05$

** Significantly different at $\mathrm{p}<0.01$

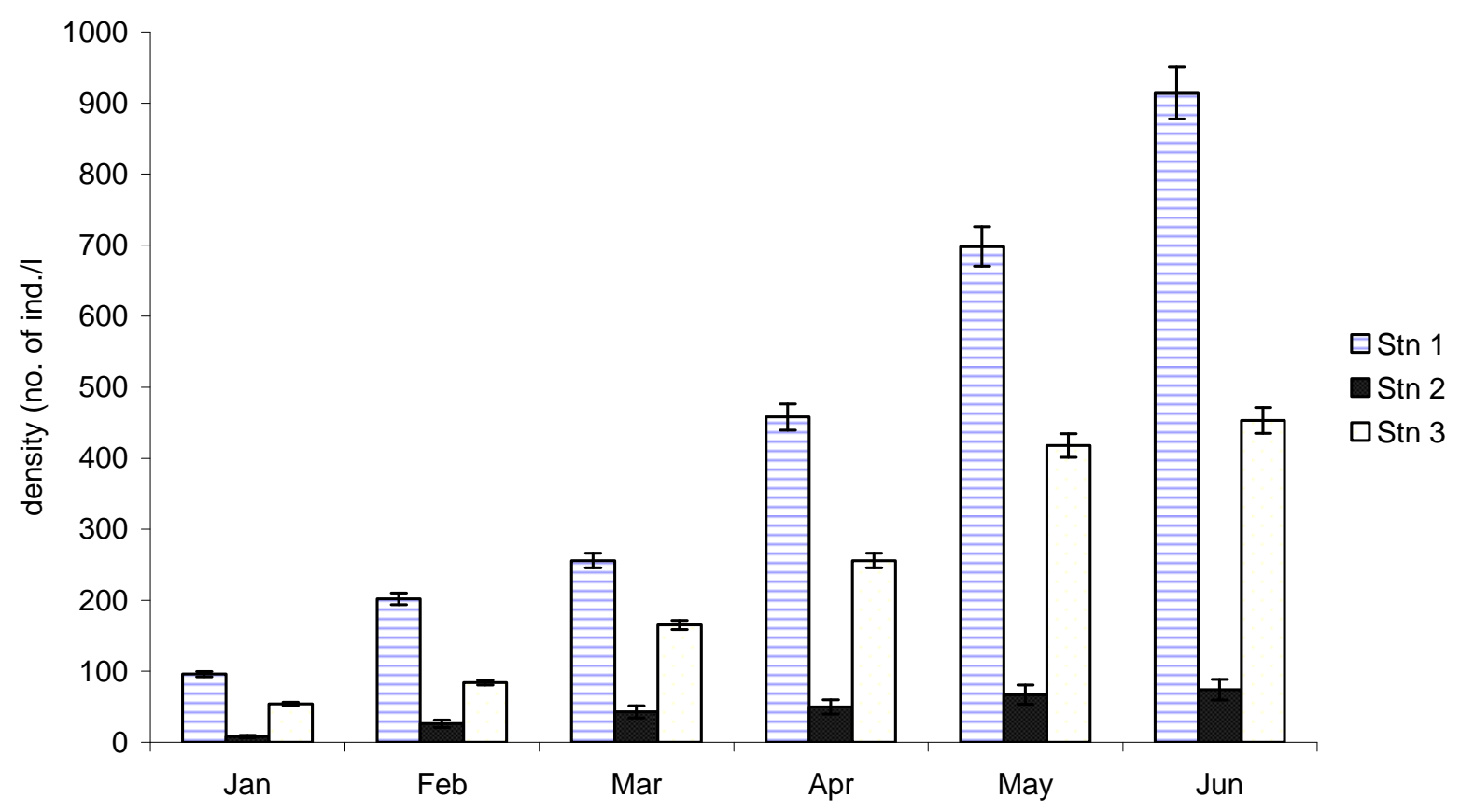

Fig. (3). Monthly abundance of zooplankton in the sampling stations of Orogodo River from January - June 2008.

station 3 recorded a total of 72 taxa. Generally, the bdelloid rotifers dominated the entire zooplankton abundance. The rotifer, Rotaria tridens was the most abundant species recorded in the study with a percentage contribution of $9 \%$ to the total zooplankton abundance. Copepods and cladocerans were well represented in stations 1 and 3 but only sporadically present in station 2 (the abattoir impacted site). Quantitatively, the rotifer, Rotaria species were the most abundant and preponderant species present in appreciable numbers in all the stations sampled. Lecane, Monostyla and Trichocerca species were the other dominant rotifer genera encountered, while Chydorus was the dominant cladoceran. Ostracods were poorly represented in the stream in terms of abundance and diversity. Only two genera, Eucypris and Nebalia were recorded sporadically in stations 1 and 3. Generally, most zooplankton species were recorded in the rainy season months (April- June) as compared to the dry season months (January - March). However, Lecane unqulata, L. papuana and Trichocerca elongata were only recorded in the dry season months. Total zooplankton abundance varied significantly $(\mathrm{p}<0.05)$ among months and inversely with depth suggesting strong seasonal effects. The minimum values were recorded $\mathrm{n}$ the dry season month of January while maximum values were recorded in the peak of the raining season (June). There was a progressive increase of abundance from January to June in all the stations examined and less evident abundance variation for station 2 between months (Fig. 3).

\section{Taxa Richness, Diversity, Evenness and Dominance Indices}

A summary of the taxa richness, diversity, evenness and dominance indices is shown in Table 4. Stations 1 and 3 recorded high taxa richness (Margalef index) and diversity index values but were low in station 2 . Similarly stations 1 
Table 4. Diversity, Evenness and Dominance Indices of Zooplankton at the Different Sampling Stations of Orogodo River

\begin{tabular}{|c|c|c|c|}
\hline & Station 1 & Station 2 & Station 3 \\
\hline No. of taxa & 78 & 22 & 72 \\
\hline Number of individuals/1 & 2624 & 268 & 1430 \\
\hline Taxa Richness (Margalef index) & 9.78 & 3.76 & 9.77 \\
\hline Shannon-wiener diversity & $1.63^{\mathrm{a}}$ & $1.19^{\mathrm{b}}$ & $1.64^{\mathrm{a}}$ \\
\hline Simpson dominance index & 0.04 & 0.08 & 0.03 \\
\hline Evenness & 0.86 & 0.78 & 0.89 \\
\hline
\end{tabular}

Note. Diversity values with the same letter superscript indicate that these values were not significant among the sampling stations (Hutcheson T-test for Comparison).

and 3 recorded higher evenness values. Simpson's dominance index values was high in station 2 compared to the other two stations examined. Hutcheson T-test for comparison between the stations revealed that the diversity between stations $1 \& 2$ and stations $2 \& 3$ were significantly different whereas the diversity between stations 1 and 3 was not significantly different.

\section{DISCUSSION}

Change in water depth was mainly due to increasing successive rainfall all throughout the months. There was a significant difference in the water depth at the different stations and this can be ascribed to the morphometry of the river bed which is uneven. The mean air and water temperature obtained are typical of tropical rivers [11]. The gradual increase in the flow velocity attained particularly in stations [2, 3] during the wet season can be attributed to high flood from precipitation and increased runoff. [15] opined that since most of the physical parameters are influenced by rainfall, rainfall regime is therefore considered a dominant factor affecting zooplankton dynamics in tropical waters. The level of nitrates was higher in station 2 and 3 indicating a substantial amount of organic input coming from effluent discharge. BOD values indicate the extent of organic pollution in aquatic system which affects the water quality [30]. Based on BOD classification, station 1 and 3 are not polluted since they have BOD ranges $2.22-2.74$ and $2.58-3.00 \mathrm{mg} / \mathrm{l}$ respectively but for station 2 it was moderately polluted since it recorded a value of $5.56 \mathrm{mg} / \mathrm{l}$. Most of the zooplankton encountered in the study area appears to be normal inhabitants of natural lakes, ponds, streams and artificial impoundments in the tropics and subtropics $[10,15,24,26,29]$, oriental regions [31] and in India [32]. The rotifers constitute the largest group of zooplankton recorded in all the sites. The ability of rotifers to undergo vertical migration, which minimizes competition through niche exploitation and food utilization, could be probably the reason for their dominance. Also, rotifer richness in the stream probably could be due to high microhabitat diversity especially at stations 1 and 3 . The dominance of rotifers in Nigerian aquatic ecosystems has been documented by several authors [17, 24, 26, 33-36]. The high population abundance of rotifer may also be attributed to their parthenogenetic reproductive pattern and short developmental rates under favourable conditions in most fresh water systems [37]. Crustacean zooplankton communi- ties in the present study were typified by the dominance of Chydoridae in terms of species richness and diversity. This finding is consistent with [38-40] in various tropical freshwater systems. Our CCA indicated that zooplankton organisms responded to a number of physicochemical variables. Dissolved oxygen, BOD, flow velocity and conductivity have been found to be important in other tropical studies [14, $16,29,33]$. The discharge of organic wastes directly into station 2 significantly reduced the dissolved oxygen in spite of the high flow velocity. Other components of the organic wastes like blood and animal faeces increased nitrate levels which in turn increased the biochemical oxygen demand values of the site. In addition, the biodegradation of the organic materials exerted oxygen tension in the water and increased the BOD [18]. The increased level of conductivity, nitrates and few other parameters are product of decomposition which was active in station 2 , while most of these impacted parameters easily recovered to their original state downstream (station 3). The abundance of zooplankton in the study area is a reflection of the stream order (1o) characterized by wide width and slow flow velocity in Station 1 and relatively fast velocity in station 3 which permitted the development of stable zooplankton community. The relatively long period of sampling (covering 3 months of dry season and 3 months of rainy season) may partly account for the rich zooplankton recorded. This is typical of all cases of organically polluted lotic water bodies [41]. Once the natural community of invertebrates and other organisms can be predicted, deviations due to organic and anthropogenic activities can be more easily accused. In our study, zooplankton abundance increased with increase in the amount of rainfall. This may be due to the ability of rains to bring in allochthonous nutrients from the drainage basin as well as the mixing of autochthonous materialsthat will accelerate primary production and as a consequence, zooplankton production and abundance $[29,42]$. This is however in contrast with the findings of [34] in Benin River and [40] in coastal western rivers of Nigeria reported negative correlation between rainfall and zooplankton abundance.

However in consonance with this investigation, [15, 43] reported rotifer maxima at the peak period of water level. They attributed the rainy season maxima to the dilution effect of salinity. The responses of zooplankton to organic effluent pollution varied greatly among families and individual species. The Rotifer families; Asplanchnidae, Branchionidae, 
Colurellidae, Dicranphoridae, Euchlanchinidae, Gastropididae, Adinetidae, Notominatidae, Testudinellidae the crustacean families; Diaptomidae, Chydoridae, Bosminidae, Sisidae and the ostracods disappeared completely in station 2 . Sensitive species normally disappears as the water becomes polluted while tolerant ones survive the pollution stress and readily recovers downstream of the point of discharge. It has been observed that different species in the same genus may react differently to pollution [44] and this was also corroborated in this investigation. The result of this study suggest that the rotifers, Itura viridis, some Lecanids, Habrotrochids, the bdelloid, Philodinavus paradoxus, philodinids, Trichocercids and Trochosphaeridae and the crustacean; Thermocyclops neglectus, Moina micrura and Diaphnosoma excisum were less sensitive to nvironmental perturbation. The unusual tolerance of the philodinids to environmental stress imposed by organic pollution has long been documented $[16,45]$. However the absence of a particular species or group from a river may not be indicative of pollution because not all reaches in a water body are suitable for all invertebrates $[46,47]$. Pearson's correlation coefficient indicated that several environmental variables exert a considerable influence on the zooplankton abundance especially dissolved oxygen, temperature, total alkalinity, total nitrogen, phosphate and $\mathrm{pH}$. Consistent with our findings, [4] reported significant multiple correlations between plankton abundance and several physical and chemical variables in their study. Our study confirms the influence of these abiotic factors on zooplankton population.

\section{CONCLUSIONS}

This study revealed that zooplankton communities responded to changes in water quality and this was seen in changes in composition of species assemblages and abundance at the various stations. Abattoir wastes, domestic wastes and residential urban settlements around Agbor area, were suspected to negatively influence environmental conditions in Orogodo River thus adversely affecting the zooplankton composition structure at station 2. The high zooplankton abundance and diversity in stations 1 and 3 was due to the high microhabitat diversity. Overall, our results showed that changes in water quality of the river have significant effects on the structure of zooplankton assemblages. This feature could be used for biomonitoring of the river health to ensure the protection of the aquatic biota. Considering the usefulness of this municipal river to the community, waste water treatment should be applied in order to minimize the influence on water quality.

\section{ACKNOWLEDGEMENTS}

The financial assistance of the Carnegie RISE Foundation for postdoctoral research of F.O. Arimoro in the Institute for Water Research, Rhodes University, South Africa is acknowledged. We are grateful to Rachael Amaka, Ogbonna Emmanuel and Akpochafo Igho for laboratory and field assistance. Also, thanks to the two anonymous reviewers for valuable comments that greatly improved the manuscript.

\section{REFERENCES}

[1] Arimoro FO, Osakwe EI. Influence of sawmill wood wastes on the distribution and population of Macrobenthic invertebrates in Benin
River at Sapele, Niger Delta, Nigeria. Chem Biodivers 2006; 3: 578-92.

[2] Zabbey N, Hart AI. Influence of some physicochemical parameters on the composition and distribution of benthic fauna in Woji creek, Niger Delta, Nigeria. Global J Pure Appl Sci 2006; 12(1): 1-5.

[3] Arimoro FO, Ikomi RB. Response of macroinvertebrates to abattoir wastes and other anthropogenic activities in municipal stream in Niger Delta, Nigeria. Environmentalist 2008: 28: 85-98

[4] Sarkar SK, Choudhury B. Role of some environmental effect on the fluctuations of plankton in a lentic pond at Calcutta. Limnological Research in India. India: Daya Publishing House 1999; pp. 108-30.

[5] Taylor V, Schulze R, Jewith G. Application of the Indicators of the hydrological alteration method to the Mkomazi River, Kwazulu Natal, South Africa. J Aquat Sci 2000; 28: 1-11.

[6] Jha P, Barat S. Hydrobiological study of Lake Mirik in Darjeeling, Himalaya. J Environ Biol 2003; 24(3): 339-44.

[7] Holz JC, Hoagland KD. Experimental microcosm study of the effects of phosphorus reduction on plankton community structure. Can J Fish Aquat Sci 1996; 53: 1754-64.

[8] Koteswari YN, Ramanibai R. Evaluation of toxicity of tannery effluent on plankton community structure: A multispecies microcosm study II. Turk J Biol 2004; 28: 55-63.

[9] El-Bassat, Taylor WD. The zooplankton of Lake Abo Zaabal, a newly-formed mining lake in Cairo, Egypt. Afr J Aquat Sci 2007; 32(2):185-92.

[10] Ayodele HA, Adeniyi IF. The zooplankton fauna of six impoundments of River Osun, southwest Nigeria. Zoologist 2005; 4: 49-67.

[11] Arimoro FO, Iwegbue CMA, Osiobe O. Effects of industrial waste water on the physical and chemical characteristics of Warri River, a coastal water body in the Niger Delta, Nigeria. Res J Environ Sci 2008; 2(3): 209-20.

[12] Aoyagui ASM, Bonecker CC. Rotifers in different environments of the upper Parana River flood plains (Brazil): richness, abundance and the relationship to connectivity. Hydrobiologia 2004; 522: 28190 .

[13] Maruthanayagam C, Sasi KM, Senthikumar C. Studies on Zooplankton population in Thirukkulam pond during summer and rainy seasons. Nat Environ Pollut Technol 2003; 2(1): 13-19.

[14] Pandey J, Verma A. The Influence of Catchment of chemical and biological characteristics of two fresh tropical lakes of southern Rajasthan. J Environ Biol 2004; 25(1): 81-7.

[15] Egborge ABM. Water pollution in nigeria: biodiversity and chemistry of Warri River. Nigeria: Ben Miller Publisher and Warri 1994: p. 254.

[16] Ogbeibu AE. Rotifers of a temporary pond in Okomu Forest Reserve. Niger J Sci Environ 1998; 1: 117-34.

[17] Ogbeibu AE, Osokpor OR. The effect of impoundment on the hydrology and rotifers of the Ikpoba River, Nigeria. Biosci Res 2004; 16(2): 132-8.

[18] Arimoro FO, Ikomi RB, Iwegbue CMA. Water quality changes in relation to Diptera community patterns and diversity measured at an organic effluent impacted stream in the Niger Delta, Nigeria. Ecol Indic 2007; 7: 541-52.

[19] APHA, American Public Health Association. Standard Methods for the Examination of Water and Wastewater, 18th ed. Washington DC: American Public Health Association 1992.

[20] Gordon ND, Mc Mahon TA, Finlayson BL. Stream hydrology, an introduction for ecologists. New York: John Wiley and Sons 1994; p. 526.

[21] Ward JV. Aquatic insect ecology. New York: John Wiley and Sons Inc. 1992; p. 438.

[22] Edmondson WT, Winberg GG. A manual on methods for the assessment of secondary productivity in freshwaters. Oxford: IBP Hand Book No. 17. Blackwell 1971; p. 358.

[23] Pennak RW. Freshwater Invertebrates of the United States. New York, NY: John Wiley \& Sons, Inc. 1978; p. 803.

[24] Jeje CY, Fernando CH. A practical guide to the identification of Nigerian zooplankton. Nigeria. Kainji Lake Research Inst Publication 1986; p. 141.

[25] Shiel RJ. A guide to identification of Rotifers, Cladocerans and copepods from Australian inland waters. Australia: The MurrayDarling Freshwater Research Centre 1995; p. 128.

[26] Aneni IT, Hassan AT. Effect of pollution on seasonal abundance of plankton in Kudeti and Onireke streams, Ibadan, Nigeria. Zoologist 2003; 2(2): 76-83. 
[27] Jckel K. Finite sample properties and asymptotic efficiency of Monte Carlo tests. J Appl Econ 1986; 14: 85-118.

[28] Ludwig JA, Reynolds JF. Statistical ecology. A primer on methods and computing. Newyork: Wiley/interscience, Wiley 1988; p. 337.

[29] Okogwu OI, Ugwumba OA. The Zooplankton and environmental characteristics of Ologe Lagoon southwest, Nigeria. Zoologist 2006; 4: 86-91.

[30] Jonnalagadda SB, Mhere G. Water quality of Odzi River in Eastern Highlands of Zimbabwe. Water Res 2001; 35: 2371-6.

[31] Idris BAG, Fernando CH. Cladocera of Malaysia and Singapore with new Records, redescriptions and remarks on some species. Hydrobiologia 1981; 97: 233-56.

[32] Arora J, Mehra NK. Species diversity of planktonic and epiphytic rotifers in the backwaters of the Delhi segment of the Yamuna River, with remarks on new records from India. Zool Stud 2003; 42(2): 239-47.

[33] Ogbeibu AE, Edutie LO. Effects of brewery effluent on the water quality and rotifers of the Ikpoba River, southern Nigeria. Afr J Environ Pollut Health 2002; 1(1): 1-12.

[34] Onwudinjo CC, Egborge ABM. Rotifers of Benin River, Nigeria. Hydrobiologia 1994; 272: 87-94.

[35] Egborge ABM, Chigbu P. The rotifers of Ikpoba River, Bendel State. Niger Field 1994; 53: 117-32.

[36] Egborge ABM, Tawari PLC. The rotifers of Warri River, Nigeria. J Plankton Res 1987; 9: 1-13.

[37] Akin-Oriola GA. Zooplankton associations and environmental factors in Ogunpa and Ona Rivers, Nigeria. Rev Biol Trop 2003; 51(2): 391-8.
[38] Dumont HJ, Pensaert J, Vande Veld I. The crustacean zooplankton of Mali (West Africa) Fauna composition, community structure and biogeography with a note on the water chemistry of the lakes of the internal Delta of River. Niger Hydrobiol 1981; 80(2): 161-87.

[39] Sharma BK, Michael RG. Review of taxonomic studies of freshwater cladocera from India with remarks on biogeography. Hydrobiologia 1987; 35: 29-34.

[40] Egborge ABM, Onwudinjo CC, Chigbu PC. Cladocera of coastal rivers of west Nigeria. Hydrobiologia 1994; 272: 39-46.

[41] Hart CW, Jr., Fuller SLH, Eds. Pollution ecology of Freshwater invertebrates. New York: Academic Press 1974.

[42] Evans B, Townsend CR, Crowl TA. Distribution and abundance of coarse woody debris in some southern New Zealand streams from contrasting forest catchments. N Z J Mar Freshw Res 1993; 27: 227-39.

[43] Imebvore AMA. The hydrology and plankton of eleiyele reservoir, Ibadan, Nigeria. Hydrobiologia 1967; 30(1): 154-74.

[44] Hynes HBN. The biology of polluted water. Toronto: University of Toronto Press 1960.

[45] Ovie SI. Brachionus species of some inland waters in Nigeria with a note on a new record and zoogeography. Trop Freshw Biol 1997; 6: 27-39.

[46] Mason CF. Biology of freshwater pollution. UK: Longman 1981; p. 239.

[47] Ali MM, Mageed AA, Heikal M. Importance of aquatic macrophyte for invertebrate diversity in large subtropical reservoir. Limnologica 2007; 37: 155-69.

(c) Arimoro and Oganah; Licensee Bentham Open.

This is an open access article licensed under the terms of the Creative Commons Attribution Non-Commercial License (http://creativecommons.org/licenses/ by-nc/3.0/) which permits unrestricted, non-commercial use, distribution and reproduction in any medium, provided the work is properly cited. 